\title{
TSH neurosecretory dysfunction (TSH-nd) in Down syndrome (DS): low risk of progression to Hashimoto's thyroiditis
}

\author{
Disfunção neurossecretora de TSH na síndrome de Down: \\ baixo risco de progressão para a tireoidite de Hashimoto
}

Claudia Dutra Costantin Faria', Simone Ribeiro', Cristiane Kochi' ${ }^{1}$, Aryane Pereira Neves da Silva², Bruna Natalia Freire Ribeiro², Lilian Teixeira Marçal'2, Felipe Henrique Yyazawa Santos², Calliari Procópio Luis Eduardo', Osmar Monte, Carlos Alberto Longui ${ }^{1,2}$

1 Pediatric Endocrinology Unit, Department of Pediatrics, Irmandade da Santa Casa de Misericórdia de São Paulo (ISCMSP), São Paulo, SP, Brazil 2 Department of Physiology, Faculdade de Ciências Médicas da Santa Casa de São Paulo (FCMSC-SP), São Paulo, SP, Brazi
Correspondence to:

Cláudia Dutra Costantin Faria

Faculdade de Ciências Médicas

da Santa Casa de São Paulo

Rua Dr. Cesário Mota Junior, 112

01221-020 - São Paulo, SP, Brazil

ceclau@terra.com.br

Received on 4/Oct/2011 Accepted on 10/Nov/2011

\section{ABSTRACT}

Introduction: Patients with Down syndrome (DS) often have elevated TSH (hypothalamic origin), which is called TSH neurosecretory dysfunction (TSH-nd). In these cases, there is slight elevation in TSH $(5-15 \mu \mathrm{Ul} / \mathrm{mL})$, with normal free T4 and negative thyroid antibodies (AB). Objective: To recognize the risk of progression to Hashimoto's thyroiditis (HT). Subjects and methods: We retrospectively analyzed 40 DS patients (mean age $=4.5$ years), followed up for 6.8 years. Results: HT was diagnosed in 9/40 patients, three early in monitoring, and six during evolution. In $31 / 40$ patients, TSH-nd diagnosis remained unchanged over the years, with maximum TSH values ranging from 5 to $15 \mu \mathrm{UI} / \mathrm{mL}$. In this group, free $\mathrm{T} 4$ also remained normal and $\mathrm{AB}$ were negative. There was a significant TSH reduction $(p=0.017)$, and normalTSH concentrations $(<5.0 \mu \mathrm{UI} / \mathrm{mL}$ ) were observed in 29/31 patients, in at least one moment. No patient hadTSH $>15 \mu \mathrm{Ul} / \mathrm{mL}$. Conclusion: DS patients with TSH-nd present low risk of progression to HT (10\% for females and 6\% for males). Arq Bras Endocrinol Metab. 2011;55(8):628-31

\section{Keywords}

Down syndrome; Hashimoto's thyroiditis; TSH neurosecretory dysfunction; isolated TSH elevation

\section{RESUMO}

Introdução: Pacientes com síndrome de Down (SD) geralmente apresentam TSH elevado (de origem hipotalâmica), uma desordem chamada de disfunção neurossecretora de TSH (TSH-nd). Nesses casos, há uma leve elevação doTSH (5-15 $\mu \mathrm{UI} / \mathrm{mL})$, com T4 livre normal e anticorpos antitireoide $(\mathrm{AB})$ negativos. Objetivo: Reconhecer o risco de progressão para a tireoidite de Hashimoto (HT). Sujeitos e métodos: Analisamos retrospectivamente 40 pacientes com SD (idade média = 4,5 anos), acompanhados por 6,8 anos. Resultados: A HT foi diagnosticada em 9/40 pacientes, três logo no início da avaliação e seis durante a evolução. Em 31/40 dos pacientes, o diagnóstico de TSH-nd permaneceu estável durante os anos, com valores máximos de TSH variando de 5 a $15 \mu \mathrm{Ul} / \mathrm{mL}$. Neste grupo, oT4 livre também permaneceu normal e os $A B$ foram negativos. Houve uma redução significativa do TSH $(p=0,017)$, e concentrações normais deTSH $(<5,0 \mu \mathrm{Ul} / \mathrm{mL})$ foram observadas em $29 / 31$ pacientes, em pelo menos um momento. Nenhum paciente apresentou TSH > $15 \mu \mathrm{UI} / \mathrm{mL}$. Conclusão: Pacientes com SD eTSH-nd apresentam baixo risco de progressão para a HT (10\% para o sexo feminino e $6 \%$ para o sexo masculino). Arq Bras Endocrinol Metab. 2011;55(8):628-31

Descritores

Síndrome de Down; tireoidite de Hashimoto; disfunção neurossecretora de TSH; elevação isolada de TSH 


\section{INTRODUCTION}

$\mathrm{D}$ own syndrome (DS) is a common chromosomal abnormality and the most common genetic cause of mental retardation (1). Autoimmune diseases, especially Hashimoto's thyroiditis (HT), are frequently observed in patients with DS. In these situations, autoantibodies $(\mathrm{AB})$ directed against the thyroid are found in $13 \%$ to $34 \%$ of patients (2). Therefore, it is suggested that thyroid function, including measurement of TSH, free $\mathrm{T} 4$ and $\mathrm{AB}$, is performed as part of routine monitoring of DS patients (3-4). Thyroid hormones have important functions in the central nervous system (CNS). They are involved in neuronal migration and differentiation, neurotransmitter synthesis and secretion, myelination, and regulation of gene expression in neuronal cells (5). Hypothyroidism is a potentially aggravating factor of neurological abnormalities of DS patients (5).

In addition to primary thyroid disease, patients with DS may present inadequate dopaminergic regulation of pituitary TSH secretion (6). These changes determine an abnormal secretion pattern, resulting in isolated TSH elevation without changes in thyroid hormones (7). In TSH neurosecretory dysfunction (TSH-nd), TSH concentrations are slight elevated $(5-10 \mu \mathrm{UI} /$ $\mathrm{mL}$ ), free $\mathrm{T} 4$ values are normal, and $\mathrm{AB}$ are negative. In most cases, there is no detectable anatomic abnormality, and the etiology is not identified. Frequency presentation is similar in males and females (7).

Despite the absence of alteration in thyroid hormones, it is questionable whether TSH-nd may reduce growth velocity in these children (8). In these cases, there is no consensus on levothyroxine replacement therapy (9).

Cutler and cols. suggested that isolated TSH elevation could be a sign of risk of progression to primary autoimmune hypothyroidism, even in the absence of detectable anti-thyroid $\mathrm{AB}$ (10).

The aim of this study was to identify a risk of progression to HT, by means of a follow up of DS patients with TSH-nd.

\section{SUBJECTS AND METHODS}

This study was based on the retrospective analysis of 40 patients with DS (mean age $=4.5$ years), both females and males, followed up at the Pediatric Endocrinology Department Unit of ISCMSP, referred to us because of previous elevated TSH and/or positive anti-thyroid $\mathrm{AB}$. The study was approved by the Ethics Committee in Human Research of the ISCMSP.
The studied variables were: weight $(\mathrm{kg})$, height $(\mathrm{cm})$, pubertal characteristics (Tanner score); T4, free T4, TSH, anti-thyroperoxidase and anti-thyroglobulin concentrations and, for some patients, thyroid ultrasound. Weight was measured on an analog scale $\left(\right.$ Filizola $\left.^{\circledR}\right)$, and height, on a wall-mounted stadiometer (Gomes \& Tonelli $^{\circledR}$ ).

Height and BMI were expressed as standard deviation $\mathrm{z}$ scores (SDS), calculated from reference values of SD patients (11).

T4, free T4 and TSH were measured by fluorometric assays (AutoDELFIA automatic immunoassay system). Anti-thyroperoxidase and anti-thyroglobulin $\mathrm{AB}$ were quantified by an immunometric assay (IMMULITE 2000). Negative results were below $35 \mathrm{IU} / \mathrm{mL}$ and $40 \mathrm{IU} / \mathrm{mL}$, respectively.

TSH-nd diagnosis was established when TSH values were slightly elevated $(5-15 \mu \mathrm{UI} / \mathrm{mL}), \mathrm{T} 4$ and free $\mathrm{T} 4$ concentrations were normal, and thyroid $\mathrm{AB}$ were negative.

Statistical analysis used SigmaStat for Windows, v.2.03 (SPSS, Chicago, Il, USA). Comparisons of initial and final values for height SDS, BMI SDS, T4, free T4 and TSH of the same patient were performed by Paired $\mathrm{T}$ test. Statistical significance was determined by $\mathrm{p}<0.05$.

\section{RESULTS}

Forty DS patients (mean age $=4.5$ years) were considered for retrospective evaluation. Three patients $(3 / 40)$ were initially excluded because they had symptoms compatible with primary hypothyroidism already at diagnosis.

During follow-up, 6/37 patients (4F: $2 \mathrm{M}$ ) initially considered as having TSH-nd presented progression to HT diagnosis, without hypothyroidism. Anti-thyroid $\mathrm{AB}$ were positive after a follow-up period ranging from 8 to 28 months.

TSH-nd diagnosis remained unchanged in thirty one individuals (12F: 19M). Median follow-up period of this subgroup was 6.8 years $(1.0-20.2)$. Mean age at first visit was 3.4 years (SDS $=3.7$ ), ranging from 0.1 to 14.3 years. Table 1 summarizes initial and final descriptive data, including anthropometric measurements and laboratory results.

In relation to anthropometric measurements, there was no reduction in growth during the observation period. Despite a significant increase in BMI in this subgroup, final BMI SDS values were not consistent with obesity diagnosis. 
Table 1. Initial and final assessment of anthropometric measurements and laboratory results of patients with DS and TSH-nd

\begin{tabular}{lccc}
\hline & $\begin{array}{c}\text { Initial values } \\
\text { (N = 31) } \\
\text { Mean (SDS) } \\
\text { Range } \\
\text { Median }\end{array}$ & $\begin{array}{c}\text { Final values } \\
\text { (N = 31) } \\
\text { Mean (SDS) } \\
\text { Range } \\
\text { Median }\end{array}$ & P value \\
\hline Height SDS & $-0.6(1.2)$ & $-0.9(0.9)$ & 0.13 \\
& $-2.7-3.0$ & $-3.0-0.9$ & \\
BMI SDS & -0.7 & -0.8 & \\
& $-0.3(1.4)$ & $0.6(1.2)$ & $0.003^{\mathrm{a}}$ \\
& $-3.3-2.2$ & $-1.4-3.5$ & \\
$\mathrm{~T} 4(\mu \mathrm{d} / \mathrm{dL})$ & 0.02 & 0.5 & \\
& $9.9(1.9)$ & $9.6(1.3)$ & 0.49 \\
& $5.3-14.0$ & $7.4-11.7$ & \\
$\mathrm{Free} \mathrm{T} 4(\mathrm{ng} / \mathrm{dL})$ & 9.5 & 9.8 & \\
& $1.4(0.2)$ & $1.4(0.3)$ & 0.42 \\
& $0.7-1.9$ & $0.9-2.5$ & \\
$\mathrm{TSH}(\mu \mathrm{U} / \mathrm{mL})$ & 1.4 & 1.3 & \\
& $7.1(3.0)$ & $5.5(2.6)$ & $0.017^{\mathrm{b}}$ \\
& $0.8-13.7$ & $1.7-11.5$ & \\
\hline & 6.8 & 5.0 & \\
\hline
\end{tabular}

Height SDS: z score standard deviation of height; BMI SDS: z score standard deviation of body

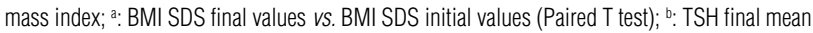
values vs. TSH initial mean values (Paired T test).

When analyzed individually, TSH peak values were slightly elevated $($ mean $=9.7 \mu \mathrm{UI} / \mathrm{mL}$, ranging from 5.4 to 15.0). There was a wide variation in $\mathrm{TSH}$, with $29 / 31$ patients $(93.5 \%)$ showing normal values in at least once during follow-up. Eleven patients $(11 / 31)$ had at least one TSH measurement between 10 and $15 \mu \mathrm{UI} / \mathrm{mL}$. Only one patient had TSH $=15 \mu \mathrm{UI} / \mathrm{mL}$, although this value was observed only once during the follow-up period of 5.4 years. Figure 1 represents TSH evolution in the subgroup of DS patients with TSH-nd during follow-up.

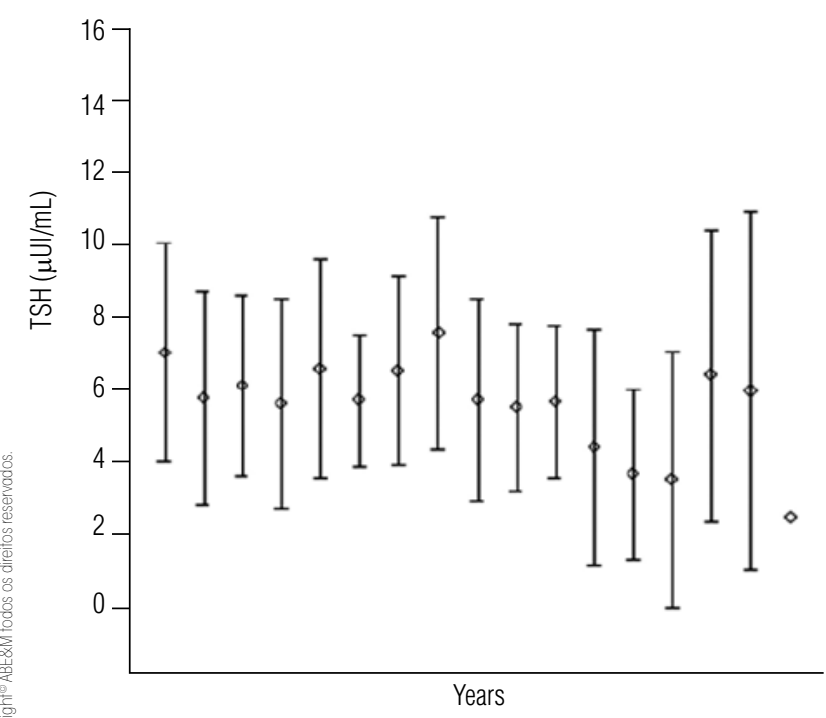

Figure 1. TSH evolution during follow-up of DS patients with TSH-nd.
Also in the TSH-nd subgroup, no patient developed hypothyroidism. By analyzing T4 and free T4 concentrations, the lowest mean individual values were respectively: $7.6 \mathrm{mg} / \mathrm{dL}$ (5.3 to 10.9 ) and $1.1 \mathrm{ng} / \mathrm{dL}(0.7$ to 1.7$)$.

Thyroid ultrasound was performed in $16 / 40$ patients. In $5 / 9$ patients diagnosed with HT, ultrasound results showed only heterogeneous texture. In $11 / 31$ patients with TSH-nd, all results were considered normal.

\section{DISCUSSION}

The close relationship between thyroid disorders and DS is well-documented (12). Considering the total universe of patients with DS, the frequency of autoimmune thyroid disease is described to be between $20 \%$ and $66 \%$, depending on the type of study, sample size, region, age group and the inclusion of hypo-or hyperthyroidism cases (13-14). It is possible that previous studies also included DS patients with TSH-nd, without $\mathrm{TH}$ and without hypothyroidism, producing a large number of false positive results.

In this study, long-term monitoring showed positive $A B$ in only $6 / 37$ patients $(16 \%)$ in a period ranging from 8 to 28 months of observation. From this total, about $10 \%$ were represented by females and $6 \%$ by males. These results corroborate literature data, which show a higher frequency of HT in girls than in pre-pubertal boys $(2: 1)(15)$.

For most patients $(31 / 37)$ analyzed in this study, there were only intermittent and isolated elevations of TSH without thyroid disease progression. For all these patients, anti-thyroid $\mathrm{AB}$ were not detected, values of free $\mathrm{T} 4$ remained normal, and there was no reduction in longitudinal growth over a mean period of 6.8 years. These long-term observations suggest that isolated elevation of TSH in DS does not seem to be a condition that predisposes to the development of thyroid disease, since in these cases, normal TSH values were often observed at some point of monitoring.

The results of this study are consistent with those of the literature. Dias and cols. (16) analyzed retrospectively 169 children with Down syndrome, with 46 patients selected for cross-sectional analysis. The authors observed a high prevalence of isolated TSH elevation (39.6\%), with slightly elevated TSH. Mean TSH values were similar to those observed in our study. These authors also observed a high frequency $(67.4 \%)$ of normal TSH values in at least one time point during the clinical follow-up. Similar to our results, they also detected a low progression to thyroid disease, and hypothyroidism 
was detected in only 4/169 of the DS patients. Thus, they concluded that isolated TSH elevation in DS children may be a transitional condition in these patients.

Other studies also observed transient elevation of TSH in DS patients. Selikowitz (17) suggested a less active form of TSH. However, Konings and cols. (18) showed normal TSH bioactivity in DS children who had subclinical hypothyroidism.

Other studies have suggested that the genesis of isolated TSH elevation in DS patients may be related to reduced dopaminergic tonus, determining increased secretion of TSH, which is related to down-regulation of thyroid TSH receptors and may maintain normal free T4 values (6).

Dopamine is a catecholamine that acts both on the hypothalamus and on D2 receptors of pituitary thyrotrophs, inhibiting the secretion of TSH. Therefore, dysfunctions of the Hypothalamic-Pituitary-Thyroid axis in patients with DS may be associated with primary thyroid diseases or with disorders of TSH secretion dependent on insufficient dopaminergic control of pituitary secretion (19).

Previous studies conducted on patients with DS reinforce the hypothesis of reduced dopamine secretion in the $\mathrm{CNS}$, and describe atrophy and reduction in the number of dopamine-producing cells in the substantia nigra at the base of the brain, and ventral tegmental area. These findings are common in individuals with DS who are over 40 years old, and occur as dementia similar to Alzheimer's disease. Just like the substantia nigra and the ventral tegmental area (important dopamine-producing areas in the brain), the arcuate nuclei of the hypothalamus (dopamine producers that act as inhibitory hormone upon TSH secretion) could also be compromised (19-21).

We concluded that patients with DS may have elevated TSH, even when thyroid hormone values are normal. Thus, caution is recommended in relation to the indication of levothyroxine replacement therapy (22), since monitoring of these patients showed long-term, low risk of progression to HT. Repeated clinical and laboratory evaluation is necessary for correct indication of treatment in DS patients who have TSH-nd.

Disclosure: no potential conflict of interest relevant to this article was reported.

\section{REFERENCES}

1. Brodtmann A. Hashimoto encephalopathy and Down syndrome. Arch Neurol. 2009;66(5):663-6.
2. Regueras L, Prieto P, Muñoz-Calvo MT, Pozo J, Arguinzoniz L, Argente J. Endocrinological abnormalities in 1,105 children and adolescents with Down syndrome. Med Clin (Barc). 2011;136(9):376-81.

3. Van Vliet G. How often should we screen children with Down's syndrome for hypothyroidism? Arch Dis Child. 2005;90(6):557-8.

4. Carroll KN, Arbogast PG, Dudley JA, Cooper WO. Increase in incidence of medically treated thyroid disease in children with Down syndrome after rerelease of American Academy of Pediatrics Health Supervision guidelines. Pediatrics. 2008;122(2):e493-8.

5. Prasher VP, Corbett JA. Thyroid function in fetuses with chromosomal abnormalities. BMJ. 1991;302(6785):1151-2.

6. Reichlin S. Neuroendocrinology of the pituitary gland. Toxicol Pathol. 1989;17(2):250-5.

7. Oliveira AT, Longui CA, Calliari EP, Ferone Ede A, Kawaguti FS, Monte $\mathrm{O}$. [Evaluation of the hypothalamic-pituitary-thyroid axis in children with Down syndrome]. J Pediatr (Rio J). 2002;78(4):295-300.

8. O'Grady MJ, Cody D. Subclinical hypothyroidism in childhood. Arch Dis Child. 2011;96(3):280-4.

9. Trbojevi B. [Subclinical thyroid disease--should we treat, should we screen for it?]. Srp Arh Celok Lek. 2003;131(11-12):467-73.

10. Cutler AT, Benezra-Obeiter R, Brink SJ. Thyroid function in young children with Down syndrome. Am J Dis Child. 1986;140(5):479-83.

11. Cremers MJ, van derTweel I, Boersma B, Wit JM, Zonderland M. Growth curves of Dutch children with Down's syndrome. J Intellect Disabil Res. 1996t;40:412-20.

12. Gibson PA, Newton RW, Selby K, Price DA, Leyland K, Addison GM. Longitudinal study of thyroid function in Down's syndrome in the first two decades. Arch Dis Child. 2005;90(6):574-8.

13. Posner EB, Colver AF. Thyroid dysfunction in Down's syndrome: relation to age and thyroid autoimmunity. Arch Dis Child. 1999;81(3):283.

14. Nisihara RM, Kotze LM, Utiyama SR, Oliveira NP, Fiedler PT, Messias-Reason IT. Celiac disease in children and adolescents with Down syndrome. J Pediatr (Rio J). 2005;81(5):373-6.

15. Zak T, Noczy ska A, Wasikowa R, Zaleska-Dorobisz U, Golenko A. Chronic autoimmune thyroid disease in children and adolescents in the years 1999-2004 in Lower Silesia, Poland. Hormones (Athens). 2005;4(1):45-8.

16. Dias VM, Nunes JC, Araújo SS, Goulart EM. [Etiological assessment of hyperthyrotropinemia in children with Down's syndrome]. J Pediatr (Rio J). 2005;81(1):79-84.

17. Selikowitz M. A five-year longitudinal study of thyroid function in children with Down syndrome. Dev Med Child Neurol. 1993;35(5):396-401.

18. Konings $\mathrm{CH}$, van Trotsenburg AS, Ris-Stalpers $\mathrm{C}$, Vulsma T, Wiedijk BM, de Vijlder JJ. Plasma thyrotropin bioactivity in Down's syndrome children with subclinical hypothyroidism. Eur J Endocrinol. 2001;144(1):1-4.

19. Krulich L. Neurotransmitter control of thyrotropin secretion. Neuroendocrinology. 1982;35(2):139-47.

20. Männistö PT. Central regulation of thyrotropin secretion in rats: methodological aspects, problems and some progress. Med Biol. 1983;61(2):92-100.

21. Zimmermann RC, Krahn LE, Klee GG, Ditkoff EC, Ory SJ, Sauer MV. Prolonged inhibition of presynaptic catecholamine synthesis with alpha-methyl-para-tyrosine attenuates the circadian rhythm of human TSH secretion. J Soc Gynecol Investig. 2001;8(3):174-8.

22. Szeliga DVM, Setian N, Passos L, Lima TMR, Kuperman H, Della Manna T, et al. Tireoidite de Hashimoto na infância e na adolescência: estudo retrospectivo de 43 casos. Arq Bras Endocrinol Metab. 2002;46/2:150-4. 